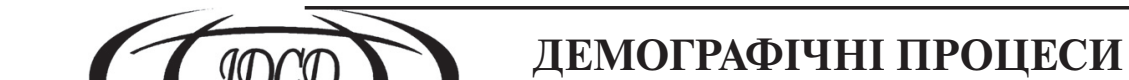

УДК 314.146

\author{
S.Y. AKSYONOVA \\ $\mathrm{PhD}$ in Economics \\ Ptoukha Institute for Demography and Social Studies \\ of the National Academy of Sciences of Ukraine, \\ 03032, Kyiv-32, bul. T. Shevchenko, 60 \\ E-mail: Svitlana_Aksyonova@yahoo.com
}

\section{ADVANCED MATERNAL AGE: THE CASE OF UKRAINE}

In Ukraine the mean age at childbirth and the mean age at birth of first child have been gradually growing since the mid-90s. This trend is similar to almost all European countries but the change of pace differs across the countries. In the present paper we examine the specific features of the "motherhood ageing" in Ukraine and its difference from European countries. As compared to these countries postponement of childbearing is a relatively recent phenomenon in Ukraine. Despite the increase in the mean age at childbirth and the mean age at first birth Ukraine is still characterised by the lowest indicators among European countries. Analysis of fertility trends and some findings of social and demographic surveys relative to reproductive intentions allow assuming that in our country the mean age of a mother at birth of child in the next 5-7 years will rise quite rapidly, and after that, the pace will slow down.

Key words: fertility, motherhood, mean age at birth, mean age at birth of the first child, postponement of childbirth.

\section{С.Ю. Аксьонова}

канд. екон.наук, провід. наук. співроб.

Інституту демографії та соціальних досліджень

ім. М.В.Птухи НАН України

E-mail: Svitlana_Aksyonova@yahoo.com

\section{ПОСТАРІННЯ МАТЕРИНСТВА В УКРАЇНІ}

В Україні з середини 1990-х років середній вік матері при народженні дитини і середній вік матері при народженні першої дитини поступово зростають. Така тенденція має місце майже в усіх європейських країнах, але темпи змін суттєво різняться між країнами. У запропонованій статті розглянуто особливості процесу «постаріння материнства» в Україні та його відмінності від аналогічних змін в європейських країнах. Відкладання дітонародження в Україні є відносно новим феноменом, і в зв'язкуз цим, незважаючи на відчутне підвищення середнього віку матері при народженні дитини і середнього віку матері при народженні первістка, рівень цих показників в Україні все ще залишається одним із найнижчих серед країн Свропи. Аналіз тенденцій народжуваності разом із результатами соціальнодемографічних обстежень щодо репродуктивних орієнтацій молодих людей дають змогу припустити, що в Україні середній вік матері при народженні дитини і середній вік матері при народженні первістка у найближчі 5-7 років зростатиме досить швидко, після чого темпи зростання значно уповільняться. 
Ключові слова: народжуваність, материнство, середній вік матері при народженні дитини, середній вік матері при народженні першої дитини, відкладання народження дитини.

\section{С.Ю. Аксёнова}

канд. экон. наук, вед. научн. сотруд.,

Институт демографии и социальных исследований

им. М.В. Птухи НАН Украины

E-mail: Svitlana_Aksyonova@yahoo.com

\section{ПОСТАРЕНИЕ МАТЕРИНСТВА В УКРАИНЕ}

В Украине с середины 1990-х годов средний возраст матери при рождении ребенка и средний возраст матери при рождении первого ребенка постепенно увеличиваются. Эта тенденция характерна почти для всех европейских стран, но темпы изменений в них существенно различаются. В предлагаемой статье рассмотрены особенности процесса «постарения материнства» в Украине и его отличия от аналогичных изменений в европейских странах. По сравнению с ними в Украине практика откладывания женщинами рождения ребенка на более поздний возраст получила распространение относительно недавно, и в связи с этим, несмотря на увеличение среднего возраста матери при рождении ребенка, Украина имеет один из самых низких показателей среди европейских стран. Анализ тенденций рождаемости и результаты социально-демографических обследований репродуктивных ориентаций молодых людей позволяют предположить, что в Украине средний возраст матери при рождении ребенка и средний возраст матери при рождении первенца в ближайшие 5-7лет будет расти довольно быстро, после чего темпы изменений существенно снизятся.

Ключевые слова: рождаемость, материнство, средний возраст матери при рождении ребенка, средний возраст матери при рождении первого ребенка, откладывание рождений.

Introduction. The present article is a continuation of the cycle of publications devoted to the age-specific fertility transformations in Ukraine, including the subject which is relevant to the last decades for our country - «ageing of motherhood» (advanced maternal age) [1]. The topic «late motherhood» is at the crossroads of many scientific research directions. Physicians, psychologists, sociologists, demographers, and teachers try to identify factors and the nature of the effects (positive or negative) accompanying this phenomenon. Both the positive and negative impacts of late motherhood on maternal and fetal outcomes are well investigated. Perhaps, the greatest concern of physicians and demographers is related to the fact that the probability of conception decreases with advanced female age. Moreover the decline in fecundity with increasing age and even if some of the assumptions are relaxed, ART (assisted reproduction technology) «in its present form cannot make up for all births lost by the natural decline of fertility after age 35» [2].

L. Schmidt, T. Sobotka, and colleagues have given review focused on the consequences of the continuing trend towards postponement of parenthood, in terms of its patterns across different countries and its demographic and medical consequences. The main idea of the research is the necessity to inform the public about the increasing reproductive risks associated with advanced female and male age to enable «people wishing to become parents make qualified decisions on when to start having children!» [3].

In Ukrainian demographical researches the advanced maternal age has been studied mostly «incidentally» in the complex works on fertility, marriage and family relations, and education development.

The main purpose of the present study is to clarify the peculiarities of the process of «ageing of motherhood» (advanced maternal age) in Ukraine in comparison with other European countries to promote the further development of more realistic hypothesis for predicting trends in fertility in our country and make more accurate projections on population dynamics. 
Basic results of the research. There is a considerable heterogeneity between and within countries in general pattern of births' postponement. Nevertheless, a general trend is observed: «in the developed world events such as leaving the parental home, forming a new union, getting married and becoming a parent are being experienced on average later in life than ever before» [4]. This trend is associated with the development of the labour market, active involvement of women in the labour force, and fertility adjustment to its institutional structures, particularly those that determine long-run unemployment rate. The research of A. Adsera evidences that in industrial countries «where long-term unemployment is rampant, childbearing occurs significantly later» [5]. Not only restriction like long-term unemployment influences postponing of childbearing but it can happen under conditions of social and economic uncertainty. Increasing uncertainty in all countries in the course of globalization changes strategies and decisions of young people in direction of postponing long-term binding relationships such as marriage and birth of (the first) child [6].

There is an opinion that changes in the mean age at childbearing indicate exhaustion of the long-term tendency to «rejuvenation» which took place in the last decades of the twentieth century in such countries as Moldova, Ukraine and Belarus [7].

The main evidence of the «motherhood ageing» phenomenon is increasing the mean age at childbirth, the mean age at first birth, intensifying fertility at maternal age of 35 and older, rising proportion of births in women aged 35 and over.

Since the mid-90s the mean age at childbirth has been gradually growing in Ukraine. Almost all European countries are facing the same problem, and, in the majority of cases, it is associated with the emergence of lowest-low fertility in Europe during the 1990s [8]. It is easy to see that the change of pace of the mean age at childbirth differs across the countries. The very rapid growth is observed in the countries which chose socialist path in the past, and in the early 1990s characterised by the lowest fertility indicators among European countries (the mean age at the first birth was within 24-26 years of age, the mean age of mothers at the first birth - within 22-24 years of age). The delay of parenthood in most of these countries was initiated with the transition to a market economy in the 1990s. As result of the rapid changes, for example, in the Czech Republic in 2012 compared with 1995 the mean mother's age at childbirth increased by $15.5 \%$ and the mean age of mothers at the first child's birth enlarged by $19.7 \%$ during that period; in Estonia indicators changed respectively by $16.1 \%$ and $15.2 \%$, in Bulgaria $-12.4 \%$ and $14.3 \%$. At the same time, the countries with the high mean age at childbearing in 1995 were characterized by low pace of growth of this indicator. In the Netherlands, the mean age at childbearing increased only by $3 \%$, but the Netherlands experienced rapid and marked postponement during the 1980s and 1990s [8], and in 1995 this country has stood out by the mean age at childbearing higher than 30 . In 2012, the high mean age at birth (more than 30) was in Spain, Italy, Ireland, and Switzerland (31.5 years). For comparison, at the same time in Ukraine the mean age at childbearing was 27.2 years (Table 1). Firstly, in consideration of the conclusion of leading Russian demographers that fertility shift towards more older parent group is a global trend and it cannot be explained by the social and economic conditions [9], secondly, in respect that Ukraine often «imitates» European trends of the majority demographic processes, and, thirdly, given the pace of current changes of indicator, we can assume that the mean age of mother at birth of child in the next 5-7 years will rise quite rapidly, and after achieving level observed now in the developed countries, the pace will slow down in our country.

In 2012, the mean age of women at the birth of their first child varied significantly across European countries from 24.1 in Moldova to 30.8 years in the United Kingdom. In the mid-90s, Moldova, Ukraine, Bulgaria, and Belarus also had the lowest mean age at first birth among European countries, and it was lower than in the Netherlands, Spain, and Switzerland by almost six years. 
Table 1. The mean age at first birth and the mean age at childbearing for selected European countries, 1995, 2000, 2005 and 2012

\begin{tabular}{|l|c|c|c|c|c|c|c|c|}
\hline \multirow{2}{*}{} & \multicolumn{3}{|c|}{ Mean age at first birth, years } & \multicolumn{3}{c|}{ Mean age at childbearing, years } \\
\cline { 2 - 10 } & $\mathbf{1 9 9 5}$ & $\mathbf{2 0 0 0}$ & $\mathbf{2 0 0 5}$ & $\mathbf{2 0 1 2}$ & $\mathbf{1 9 9 5}$ & $\mathbf{2 0 0 0}$ & $\mathbf{2 0 0 5}$ & $\mathbf{2 0 1 2}$ \\
\hline Moldova & $22.1^{*}$ & $22.7^{*}$ & $23.3^{*}$ & 24.2 & $25.1^{*}$ & $25.5^{*}$ & $26.2^{*}$ & 26.9 \\
\hline Ukraine & $22.2^{* *}$ & $22.8^{* *}$ & $23.5^{* *}$ & 24.5 & $24.4^{* *}$ & $24.9^{* *}$ & $25.8^{* *}$ & 27.2 \\
\hline Belarus & $22.9^{*}$ & $23.3^{*}$ & $23.9^{*}$ & 25.0 & $25.1^{*}$ & $25.6^{*}$ & $26.2^{*}$ & 27.5 \\
\hline Bulgaria & 22.4 & 23.5 & 24.6 & 25.6 & 24.1 & 25.0 & 26.0 & 27.1 \\
\hline Romania & 23.0 & 23.6 & 24.7 & 25.7 & 25.0 & 25.7 & 26.5 & 27.2 \\
\hline Estonia & 23.0 & 23.9 & 25.1 & 26.5 & 25.5 & 26.9 & 28.1 & 29.6 \\
\hline Poland & 23.7 & 24.5 & 25.7 & 26.6 & 26.9 & 27.3 & 28.2 & 28.9 \\
\hline Hungary & 23.8 & 25.1 & 26.6 & 27.7 & 26.3 & 27.3 & 28.4 & 29.4 \\
\hline Czech Republic & 23.3 & 25.0 & 26.6 & 27.9 & 25.8 & 27.2 & 28.6 & 29.8 \\
\hline Norway & 26.4 & 26.9 & 27.7 & 28.4 & 28.8 & 29.3 & 29.8 & 30.3 \\
\hline Slovenia & 24.9 & 26.5 & 27.7 & 28.5 & 27.1 & 28.2 & 29.4 & 30.1 \\
\hline Finland & 27.2 & 27.4 & 27.9 & 28.5 & 29.3 & 29.6 & 29.9 & 30.4 \\
\hline Portugal & 25.7 & 26.5 & 27.3 & 28.6 & 28.0 & 28.6 & 29.3 & 30.2 \\
\hline Austria & 25.7 & 26.4 & 27.3 & 28.7 & 27.7 & 28.2 & 29.0 & 30.2 \\
\hline Denmark & 27.4 & 27.8 & 28.4 & 29.0 & 29.2 & 29.7 & 30.2 & 30.7 \\
\hline Sweden & - & 27.9 & 28.7 & 29.1 & 29.2 & 29.9 & 30.5 & 30.9 \\
\hline Netherlands & 28.4 & 28.6 & 29.0 & 29.3 & 30.0 & 30.3 & 30.6 & 30.9 \\
\hline Greece & 26.6 & 28.0 & 28.5 & 29.7 & 28.2 & 29.5 & 29.9 & 30.7 \\
\hline Spain & 28.4 & 29.1 & 29.4 & 30.3 & 30.0 & 30.7 & 30.9 & 31.6 \\
\hline Switzerland & 28.1 & 28.7 & 29.5 & 30.3 & 29.4 & 29.8 & 30.6 & 31.5 \\
\hline United Kingdom & 28.3 & 29.1 & 29.9 & 30.8 & 28.2 & 28.5 & 29.1 & 29.8 \\
\hline
\end{tabular}

Source: Eurostat. Statistics: Database available at: http://epp.eurostat.ec.europa.eu/portal/page/portal/population/ data/database

* Основные вызовы демографической безопасности: сходства и различия в Молдове и Беларуси / Acad. de Etiinюe a Rep. Moldova. - Ch.: O.E.P. Etiinюa, 2010. - 296 p.

** Calculated by the author based on data of the State statistic Committee.

In the Czech Republic increasing in the mean birth intervals, especially between the first and second births shows that «not only first births have been postponed, but many women also delayed births of their second and third child» [10]. In Ukraine analysis of dynamic changes in the mean age at childbearing depending on different parity has shown that «fertility ageing» is manifested more clearly in the first and second parity but the increasing mean maternal age at birth more high parities (third, fourth and more) is less noticeable [11, p. 121]. It is logical that the postponement of the first childbirth leads to postponement of the second childbirth, and an increasing share of «women entering motherhood in their early thirties lead to an increasing proportion giving birth to their second child after the age of 35» [12].

Figure 1 shows the cumulative fertility rate by the age of 25 across birth cohorts, 1945-1986 in Czech Republic, Hungary, Sweden, France and in Ukraine. The paths in 
change of the cumulative cohort fertility rates in Sweden and France are different from those that are observed in the Czech Republic, Hungary and Ukraine. In Sweden and France the long decreasing the cumulative cohort fertility rates at age 25 for the post-war generation has gradually changed to some steadying rate for the cohorts of women born after the 1970s. In Ukraine, the largest cumulative cohort fertility rates upon reaching the age of 25 years are observed in the generation of women born in 1963-1966, that is most likely associated with measures of population policy in the early 1980s, when those women entered into active childbearing age.

The Czech Republic attracted the attention when compared to other countries. In the Czech Republic «women born up to the mid-1960s had experienced most of their childbearing before 1990 and their fertility histories are typical of the «state socialist» era» [10]. But women born in the early 1970s are characterised with some different fertility pattern. Many Czech women had become mothers at the young age, following the fertility model of the socialist era. In the early 1990s women who were still childless had interrupted the initial course of their generation's fertility pattern and delayed childbearing until the later age [10].

In 2012 the Multiple Indicator Cluster Survey (MICS-2012) was carried out in Ukraine. The survey identified an essential pattern of fertility: the share of women who gave birth by the age of 20-25 increases with the age of women representing different generations. Among interviewed women aged 25-29 years $13.6 \%$ had first birth by the age of 20, but the percentage of women who gave birth by the age of 20 in the age group of 40-44 was twice higher (26.9\%); every second interviewed woman aged 25-29 had first birth by the age of 25, but among women aged 40-44 every three to four had first birth by the age of 25 [13,97-98].

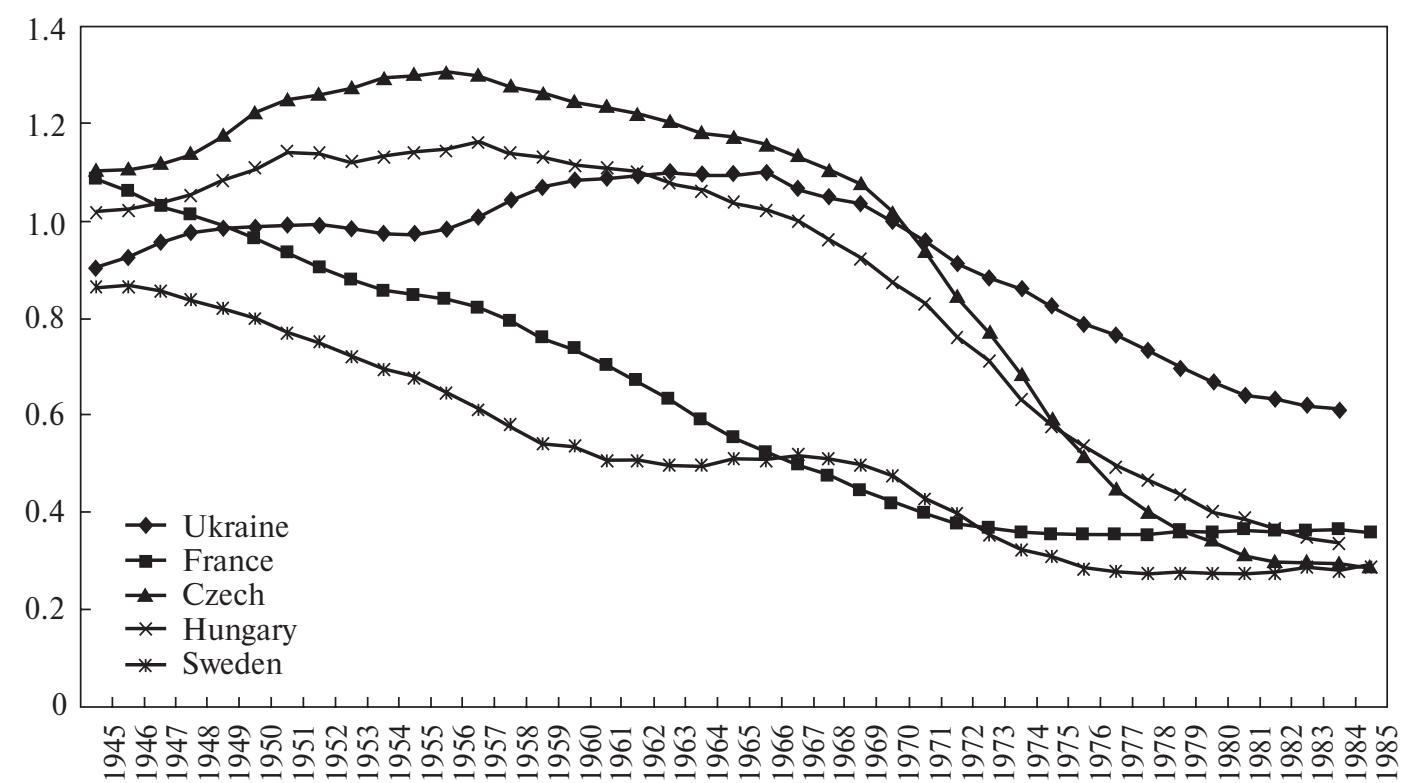

Fig. 1. Cumulative fertility rate by the age of 25 across birth cohorts, 1945-1986

Source: Human Fertility Database. Max Planck Institute for Demographic Research (Germany) and Vienna Institute of Demography (Austria). Available at: www.humanfertility.org 
F.Billari, A.Liefbroer, and D. Philipov consider the general trend towards postponement as an important element of the concept of Second Demographic Transition. Among probable causes of postponement of childbearing they focus on ideational change (emphasis was done on individual autonomy, the rejection of institutional control, the rise of values associated with the satisfaction of individuals «higher-order needs», and the growth in gender equality), the rise of women's human capital (a woman's higher educational level is associated with later transition to motherhood), gender equality and the increase in uncertainty combined with policy changes [14]. But in the opinion of H. P. Blossfeld Theory of Globalization/Rising Uncertainty can be useful for explaining nuptuality/fertility declining in former socialist countries: «uncertain youth shift long-term self-binding decisions (such as marriage and birth of child) to higher ages» [6]. In Ukraine according to the findings of sampling socio-demographic survey of childbearing-age population «Family and Family Relations» among the mentioned by respondents numerous reasons for delaying the birth of the first/next child the «intention to wait until the situation in the country becomes socially and politically stabile» is included in top five most important causes. But «intentions to improve well-being and financial situation» and «intentions to create appropriate housing conditions» have a strong lead holding the first and second top positions in the rating, and young respondents with no parenting experience have pointed out these reasons for delaying the birth of the first child more frequently in comparison with respondents who already have children. The factor of housing conditions ranged from $48 \%$ among respondents without children to $22 \%$ among those who already had three or more children [15]. So for Ukrainian youth confidence and certainty at the micro level (as their welfare) is even more important than at the macro level (as social and political stability).

Among other factors of the increase in the mean age at birth modern contraception, especially the contraceptive pills, is considered most intently as they have vastly improved women's abilities to plan pregnancy and postpone childbearing to later age [16]. In our opinion improving contraception, reducing the risks of its use, expansion and availability, has become a practical necessity [17], as it enables the free women to function in the new conditions of social development. In addition it is well founded evidence that after 2000 the first abortion risk started to decline [20].

The shift of childbearing to a later age is affected by changes in the family values, rise in gender equality and women's earning power that made women much less dependent on their male partners [3].

In Ukraine the postponement of childbearing is still a relatively recent phenomenon. But our country already exemplifies the fact that the relationship between low fertility and substantial delays in childbearing can be ambiguous. In particularly lowest-low fertility is not inevitably associated with a delay of childbearing [18]: in Ukraine during the early 1990s the mean age at first birth decreased along with a decline in fertility level period (this pattern is shared by other several former Soviet Republics). At the same time marked postponement does not necessarily imply lowest-low fertility [18]: at the beginning of the new millennium in our country delays in the timing of the first births have been accompanied with moderate growth of the total fertility rate (Fig. 2).

We can slightly lift the veil to clarify «what extent the mean age of mothers at birth may be increased» due to answers to questions of the third wave of the European Social Survey: «After what age would you say a woman is generally too old to consider having any more children (in the sense of either the first or any additional children a woman may have» ${ }^{1}$. For total number of respondents for women the mean age at childbearing after which she is generally too old to consider having any more children is 41.6 years.

${ }^{1}$ ESS: «The Timing of Life: The Organization of the Life Course in Europe». http://www.europeansocialsurvey. org/index.php?option=com_content\&view=article\&id=220:r3-rotating\&catid=116:questionnaire\&Itemid=309 


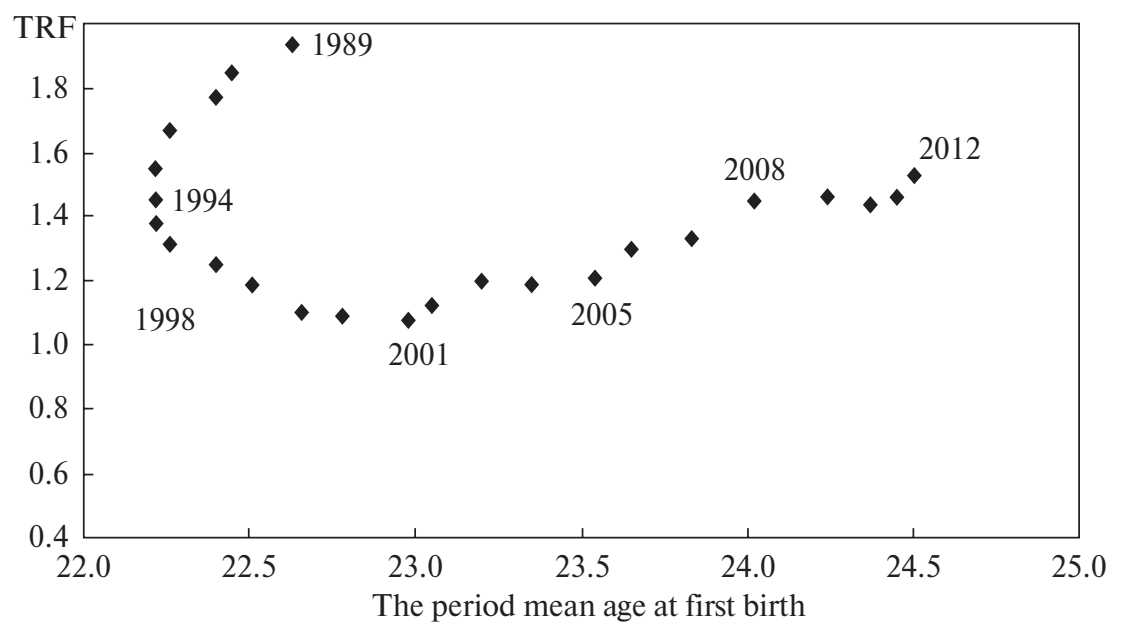

Fig. 2. Total fertility rate according to the mean age at first birth

Source: author's calculations according to the State Statistics Service.

This indicator slightly varies from 39.1 years in Hungary to 43.8 years in Austria. In Ukraine the mean age of woman when she is generally «too old to birth of child» is 42 years, and it is similar to France and Ireland. Along with Austria, Estonia stands out by high age when in the opinions of respondents a woman can still have children (43.3 years). The most popular answer in all European surveyed countries, except Austria, was 40 years (mode age). The percentage of respondents in Ukraine who indicated 40 years as age when woman is generally too old to consider having any more children was equal almost $46 \%$. These finding along with the results of other socio-demographic surveys conducted in Ukraine, which showed that 55\% of respondents said they would like to give birth to two children and $15.3 \%$ expressed a preference for three and more children [15], and awareness of the need to observe some intervals between births, confirm that in Ukraine as the mean age at birth will approach to the 30 -year-old for women the change of this indicator will significantly slow down.

It is advisable to examine the proportion of women aged 40 or older who had childbirth in Ukraine and other European countries. Figure 3 shows the proportion of children born to women aged 40 and over among all newborn children in European countries. The ranking by share clearly demonstrates that the proportion of children born to women in the older reproductive age ( 40 and over) among all births in the countries which had socialist development in the past is less than 3\%; in Ukraine this percentage is 1.6\%, but in Belarus and the Republic of Moldova it is even lower. The highest proportion of children born to women aged 40 and over among all born is $7.3 \%$ in Italy, and about 5\% in Spain, Ireland, Greece.

It is worth mentioning here that in demographic history of Ukraine the proportion of children born to women aged 40 and over among all newborn never exceeded $3 \%$. The highest level was in the second half of 1960 (2.5-2.6\%). The noticeable modern feature of fertility in Ukraine is gradual increasing of the share of children born to women aged 40 and over (since 2008), but this indicator has not reached the level of the mid-60s (in 2013-1.7\%).

It is well known that the proportion of children born to women in older reproductive age is influenced by the parity of birth. Medical concerns are related to the first birth in later age that increases the risk outcomes of both mother and child. So it is logical to consider the proportion of first births to women aged 40 and older. In Ukraine this indicator in recent years was less than $0.5 \%$. The highest percentage of first-born to women aged 40 years and older in total number 
of first births was in Spain - 5\%; in Greece, Switzerland, Ireland the share slightly exceeds 3\%, while in Poland, Slovakia, the Czech Republic it is relatively low $-0.5-0.8 \%$.

In Ukraine since 2001 the age-specific fertility rates have increased almost for all age groups of women but while fertility of women aged under 30 have demonstrated slow rise (and even in some years reduction was observed), the birth rates for women aged 30 and over have risen steadily.

Compared to 2000 the birth rate for women aged 30-34 has risen 2.3 times, the birth rate for women aged 35-39 has more than tripled. The fertility of women aged 40-44 has markedly grown (2.7 times), but while in Ukraine only five women aged 40-44 per 1,000 women of this age group have a child, in Iceland, Italy, Spain, and Sweden this indicator was three times higher. Another example is Ireland which has the highest age specific fertility rates for women age 40-44 in Europe - 22.6\% in 2012 (Fig. 4). However, the retrospective analysis of fertility of women aged 40 and older in Ukraine shows that despite the fertility rates increasing these rates have remained significantly lower than in the early 1960s.

In Ukraine the birth rate for women aged 45-49 is considerably lower than in other countries of Europe. Only two women aged 45-49 per 10,000 have childbirth in that age, whereas in Greece this indicator is almost 15 , in Ireland - 13, Italy - 11. But, on the other hand, in Ukraine the fertility rate for women aged 45-49 is higher than in Belarus and Mol-dova, so it means that «ageing of motherhood» in Ukraine appears stronger than in these countries.

Conclusions. In Ukraine since the mid-1990s young people have been increasingly delaying the start of family formation and parenthood. As a result, in our country the mean age at childbearing and the mean age at birth of first child have been gradually increasing. Almost all European countries faced this process but the pace has changed differently across the countries. In Eastern Europe the first-time mothers are markedly younger than in

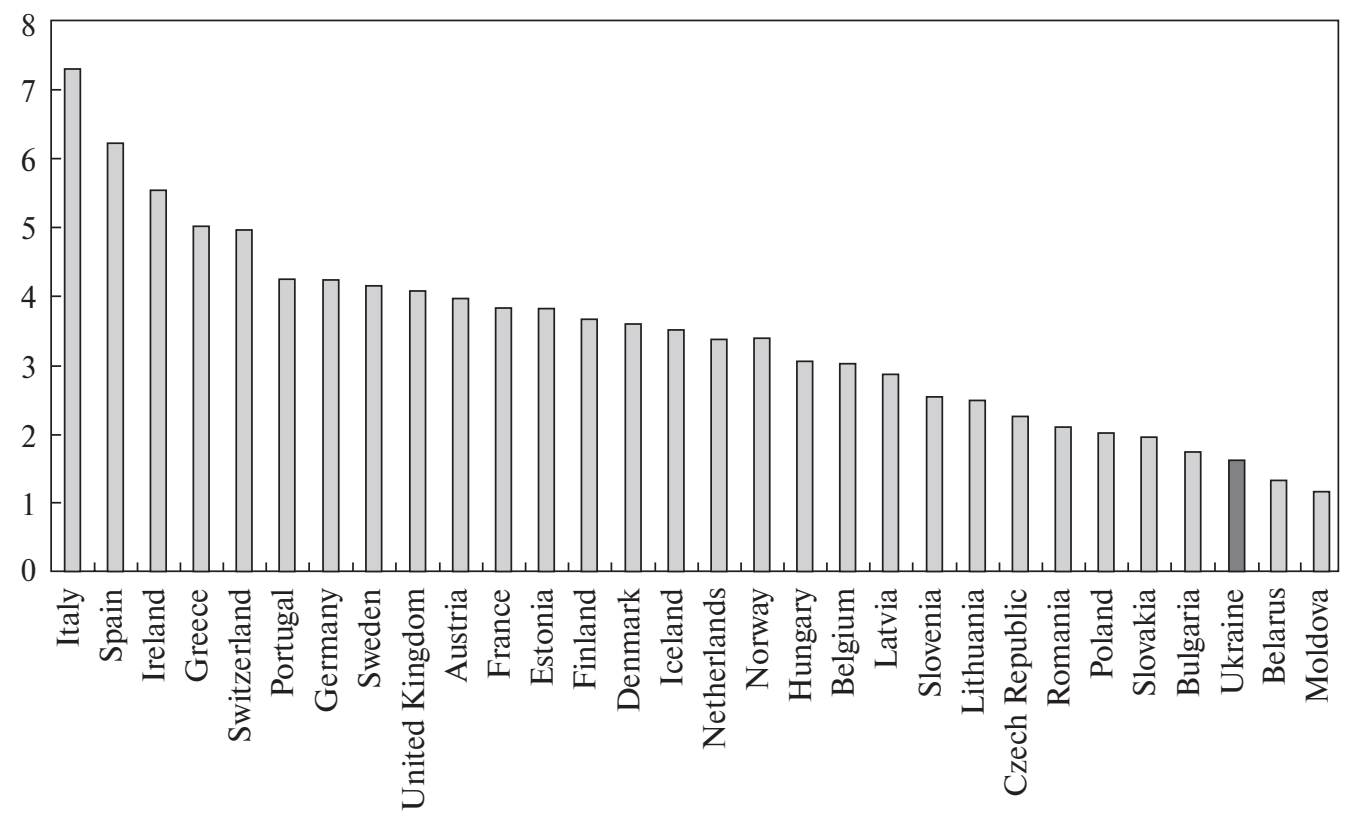

Fig. 3. Share of live births to mothers aged 40 or over by European countries

Source: European Commission. Eurostat. Population. Data. Database http://epp.eurostat.ec.europa.eu/portal/page/ portal/population/data/database 


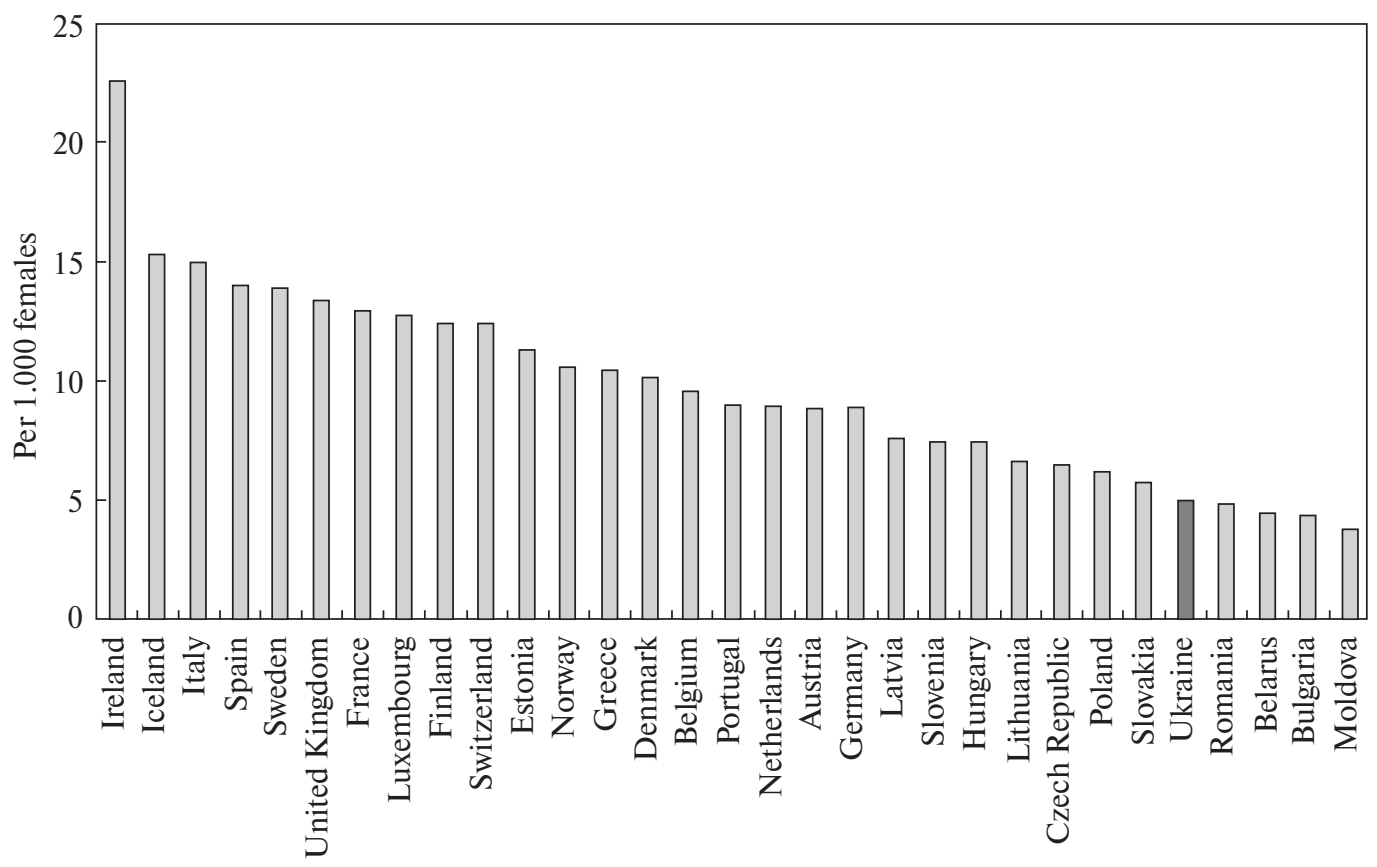

Fig. 4. Age specific fertility rate for women aged 40-44 by European countries, 2012, per 1,000 women

Source: European Commission. Eurostat. Population. Data. Database available at: http://epp.eurostat.ec.europa.eu/ portal/ page/ portal/ population/data/database

Western, Southern and Northern Europe. But in the countries of the former Soviet Union the mean age at first birth is even lower. In Ukraine the mean age of first-time mothers has extended to 24.6 years in 2013 ( 2 years increasing in comparison with the middle of 1990s) while in most developed European countries the mean age at first birth reached around $28-29$ years in the last years.

In Ukraine the majority of all births (62\%) are concentrated among women aged 20-29. However fertility rates are rising most rapidly among women over 35 years old. At the same time the proportion of births among women aged 35 and over don't exceed $11 \%$ of total fertility in our country, the share of children born of mother aged 40 or over doesn't exceed $2 \%$ of all newborns and remains below levels reached in Ukraine in the middle of 1960s. At the same time, in most developed countries the proportion of births of women aged 40 and over is between 3 and 5\% of total fertility. So, compared with European countries, in Ukraine the postponement of childbearing is a relatively recent phenomenon and despite a marked increase the mean age at childbirth and the mean age at first birth Ukraine is still characterised by the lowest indicators among European countries.

\section{LITERATURE}

1. Аксьонова С.Ю. Особливості народжуваності у жінок середнього віку // Демографія та соціальна економіка - 2009. - № 2.- С. 28-38.

2. Leridon $H$. Can assisted reproduction technology compensate for the natural decline in fertility with age? A model assessment // Human Reproduction, 2004. - 19. - P. 1548-1553.

3. Schmidt L., Sobotka T., Bentzen J.G., and Nyboe A. Andersen Demographic and medical consequences of the postponement of parenthood // Human Reproduction Update, 2012. - 18, No.1.- P. 29-43. - 
[Electronic recourse].- Accessed mode: http://connection.ebscohost.com/c/articles/69709307/demographic-medical-consequences-postponement-parenthood

4. Billari F.C., Liefbroer A.C., and Philipov D. The Postponement of Childbearing in Europe: Driving Forces and Implications // Vienna Yearbook of Population Research. - 2006. - P. 1-17.

5. Adsera A. Vanishing Children: From High Unemployment to Low Fertility in Developed Countries // American Economic Review. - 2005. - 95 (2). - P. 189-193.

6. Blossfeld, H-P. Globalization, Uncertainty and Fertility Decisions of Young People in Modern Societies [Electronic recourse].-Accessed mode:www.oeaw.ac.at/.../Wien_1_12_2005_Presentation_Blossfeld\%20no.pdf

7. Основные вызовы демографической безопасности: сходства и различия в Молдове и Беларуси // Acad. de Etiinюe a Rep. Moldova. - Ch.: O.E.P. Etiinюa, 2010. - 296 p.

8. Billari F.C., Kohler H-P. Patterns of Lowest-Low Fertility in Europe // Working papers of the Max Planck Institute for Demographic Research September 3, 2002 [Electronic recourse].- Accessed mode: www.demogr.mpg.de/papers/.../wp-2002-040.pdf

9. Вишневский А.Г. Демографический прорыв или движение по кругу? Постарение материнства способствовало росту текущих показателей рождаемости // Демоскоп. - № 533 - 534, декабрь 2012 [Electronic recourse]. - Accessed mode: http://demoscope.ru/weekly/2012/0533/tema04.php

10. Sobotka T., Stástná A., Zeman K., Hamplová Dana, Kantorová, V. Czech Republic: A Rapid Transformation of fertility and family behaviour after the collapse of state Socialism // Demographic Research, 14 (2008), P. 403-454. [Electronic recourse].- Accessed mode: http://www.demographic-research.org/

11. Населення України. Народжуваність в Україні у контексті суспільно-трансформаційних процесів - К. : АДЕФ-Україна, 2008. - 288 с.

12. Trude Lappegerd New fertility trends in Norway // Demographic Research. - 2, Article 3. - 2000 [Electronic recourse].- Accessed mode: http://www.demographic-research.org/Volumes/Vol2/3/ 15 March 2000

13. Ukraine Multiple Indicator Cluster Survey 2012, Final Report. Kyiv, Ukraine: State Statistics Committee and the Ukrainian Center for Social Reforms. - 2013. - 427 p.

14. Billari F.C., Liefbroer A.C., and Philipov D. The Postponement of Childbearing in Europe: Driving Forces and Implications // Vienna Yearbook of Population Research. - 2006. - P. 1-17.

15. Сім'я та сімейні відносини в Україні: сучасний стан і тенденції розвитку. - К. : ТОВ «ОсноваПринт», 2009. - 248 c. Family and Family Relations in Ukraine: modernity and development trends. К. : ТОВ «Основа-Принт», 2009. - 248 р.

16. Dirk J. van de Kaa On the Societal Impact of Modern Contraception // The Future of Motherhood in Western Societies: Late Fertility and its Consequences. - 2011. - P. 49-60.

17. Трансцендентальна свобода як підстава практичної необхідності // Філософія права [Електронний ресурс].- Режим доступу: http://djerelo.com/component/content/article?id=10341

18. Kohler H-P., Billari F.C., Ortega J.A. The Emergence of Lowest-Low Fertility in Europe During the 1990s // Population and Development Review. - 28, Issue 4. - 2002.- p. 641-680.

19. European Social Survey: «The Timing of Life: The Organization of the Life Course in Europe» [Electronic recourse]. - Accessed mode: http://www.europeansocialsurvey.org/index.php?option=com_content$\&$ view $=$ article \&id=220:r3-rotating\&catid=116:questionnaire \& Itemid $=309$

20. Levchuk N., Perelli-Harris B. (2009) Declining fertility in Ukraine: What is the role of abortion and contraception? MPIDR Working Paper WP-2009-045, 46 pages (2009) // Rostock, Max Planck Institute for Demographic Research [in English] [Electronic recourse]. - Accessed mode: http://www.demogr. mpg.de/en/projects_publications/publications_1904/mpidr_working_papers/declining_fertility_in_ukraine_what_is_the_role_of_abortion_and_contraception_3636.htm

\section{REFERENCES}

1. Aks'onova S. (2009) Osoblyvosti narodzhuvanosti u zhinok seredn'oho viku [The Features of fertility of women aged 35 to 39] Demografiya ta socialna ekonomika - Demography and social economy, 2, 28-38 [in Ukrainian].

2. Leridon, H. (2004). Can assisted reproduction technology compensate for the natural decline in fertility with age? A model assessment. Human Reproduction, 19, 1548-1553 [in English].

3. Schmidt, L., Sobotka T., Bentzen, J.G., and Nyboe, A. Andersen. (2012). Demographic and medical consequences of the postponement of parenthood, Human Reproduction, Vol.18, 1, 29-43 Retrieved from: 
http://connection.ebscohost.com/c/articles/69709307/demographic-medical-consequences-postponement-parenthood [in English].

4. Billari, F.C., Liefbroer, A.C., and Philipov, D. (2006). The Postponement of Childbearing in Europe: Driving Forces and Implications. Vienna Yearbook of Population Research [in English].

5. Adsera, A. (2005). Vanishing Children: From High Unemployment to Low Fertility in Developed Countries, American Economic Review, 95(2), 189-193 [in English].

6. Blossfeld, H-P. Globalization, Uncertainty and Fertility Decisions of Young People in Modern Societies Retrieved from: www.oeaw.ac.at/.../Wien_1_12_2005_Presentation_Blossfeld\%20no.pdf [in English].

7. Osnovnyie vyizovyi demograficheskoy bezopasnosti: shodstva i razlichiya v Moldove i Belarusi [The main challenges of demographic security: similarities and differences in Moldova and Belarus] (2010). Acad. Ştiințe a Rep. Moldova. Chisinau [in Russian].

8. Billari, F.C., Kohler, H-P. (2002). Patterns of Lowest-Low Fertility in Europe. Working papers of the Max Planck Institute for Demographic Research. Retrieved from: www.demogr.mpg.de/papers/.../wp2002-040.pdf [in English].

9. Vishnevskiy, A.G. (2012). Demograficheskiy proryiv ili dvizhenie po krugu? Postarenie materinstva sposobstvovalo rostu tekuschih pokazateley rozhdaemosti [Demographic breakthrough or move in a circle? Aging mothers contributed to the growth of current fertility] Demoskop - Demoscope, № 533, 534. Retrieved from: http://demoscope.ru/weekly/2012/0533/tema04.php [in Russian].

10. Sobotka, T., Štastná, A., Zeman, K., Hamplová, Dana, Kantorová, V. (2008). Czech Republic: A Rapid Transformation of fertility and family behaviour after the collapse of state Socialism, Demographic Research, 14, p. 403-454. - Retrieved from: http://www.demographic-research.org/ [in English].

11. Naselennya Ukrayiny. Narodzhuvanist'v Ukrayini u konteksti suspil'no-transformatsiynykh protsesiv [The population of Ukraine. The fertility in Ukraine in the context of social and transformation processes] (2008) Kiev: ADEF-Ukrayina [in Ukrainian].

12. Trude, Lappegerd. (2000). New fertility trends in Norway. Demographic Research, Volume 2, Article 3. Retrieved from: http://www.demographic-research.org/Volumes/Vol2/3/ [in English].

13. Ukraine Multiple Indicator Cluster Survey 2012. Final Report. Kyiv. Ukraine: State Statistics Committee and the Ukrainian Center for Social Reforms. [in English].

14. Billari, F.C., Liefbroer, A.C., and Philipov, D. (2006). The Postponement of Childbearing in Europe: Driving Forces and Implications. Vienna Yearbook of Population Research [in English].

15. Sim'ya ta simeyni vidnosini v Ukraini: suchasniy stan i tendentsii rozvitku [Family and Family Relations in Ukraine: modernity and development trends]. (2009). Kyiv: TOV «Osnova-Print». [in Ukrainian] [in English].

16. Dirk, J. van de Kaa. (2011). On the Societal Impact of Modern Contraception. The Future of Motherhood in Western Societies: Late Fertility and its Consequences [in English].

17. Transtsendentalna svoboda yak pidstava praktichnoi neobhidnosti, Filosofiya prava [Transcendental freedom as the basis of practical need, Legal Philosophy] Retrieved from: http://djerelo.com/component/content/article?id=10341 [in Ukrainian].

18. Kohler, H-P, Billari, F.C., Ortega, J.A. (2002). The Emergence of Lowest-Low Fertility in Europe During the 1990s. Population and Development Review. Volume 28, Issue 4, pp. 641-680 [in English].

19. European Social Survey: «The Timing of Life: The Organization of the Life Course in Europe». Retrieved from: http://www.europeansocialsurvey.org/index.php?option=com_content\&view=article\&id=220: r3-rotating\&catid=116:questionnaire \&Itemid=309 [in English].

20. Levchuk, N., Perelli-Harris, B. (2009). Declining fertility in Ukraine: What is the role of abortion and contraception? MPIDR Working Paper WP-2009-045, 46 pages. Rostock, Max Planck Institute for Demographic Research. Retrieved from: http://www.demogr.mpg.de/en/projects_publications/publications_1904/mpidr_working_papers/declining_fertility_in_ukraine_what_is_the_role_of_abortion_and_contraception_3636.htm [in English].

Стаття надійщла до редакції журналу 29.07.2014 